\title{
Ghrelin neutralization during fasting-refeeding cycle impairs the recuperation of body weight and alters hepatic energy metabolism
}

\author{
Susana Sangiao-Alvarellos, Steffen Helmling, María J. Vázquez, Sven Klussmann, \\ Fernando Cordido
}

\begin{abstract}
Ghrelin, a hormone whose levels increase during food deprivation, plays a pivotal role in the regulation of food intake, energy metabolism and storage, as well as in insulin sensitivity. Here, we investigated the effects of acylghrelin neutralization with the acyl-ghrelin-binding compound NOX-B11(2) during the fasting-refeeding cycle. Our data demonstrate that ghrelin neutralization with NOX-B11(2) impairs recuperation of lost body weight after food deprivation. Analysis of enzymes involved in glucose and lipid metabolism in liver of fed, fasted and refed rats revealed that neutralization of acyl-ghrelin resulted in minor decreases in the enzymes of glycolytic and lipogenic pathways during fasting. However, during refeeding these enzymes as well as glycogen levels recovered more slowly when acyl-ghrelin was blocked. The high levels of ghrelin in response to food deprivation may contribute to an adequate decrease in hepatic glycolytic and lipogenic enzymes and aid in the recovery of body weight and energetic reserves once food becomes available after the fasting period.
\end{abstract}

\begin{abstract}
Abbreviations
6PGDH, 6-phosphogluconate dehydrogenase; ACC $\alpha$, acetyl-CoA carboxylase alpha; ACL, ATP citrate lyase; AKT, total serine/threonine kinase protein kinase B; AMPK $\alpha$, 5'AMP-activated protein kinase alpha; CPT1A, liver isoform of carnitine palmitoyltransferase1; FAS, fatty acid synthase; FBase, fructose bisphosphatase; G6PDH, glucose-6phosphate dehydrogenase; GK, glucokinase; GOAT, ghrelin O-acyltransferase; HK, hexokinase; IR, insulin receptor; LPL, lipoprotein lipase; PK, pyruvate kinase; SCD-1, stearoyl-CoA desaturase-1
\end{abstract}

Keywords

Ghrelin; Liver; Fasting; Refeeding; Lipid and glucose metabolism

\section{Introduction}

Energy homeostasis is a complex and tightly regulated process under control of neural and endocrine inputs. The survival of animals is intimately linked with the drive to find and accumulate food. It has been hypothesized that the scarcity of food throughout evolution favored dominant genetic pathways leading to increased caloric intake over mechanisms that cause reduction in energy intake (Ames, 2006). However, currently in Western societies obesity and its co-morbidities are the fastest growing health problem. Available pharmaceuticals have poor efficacy and are associated with undesirable side effects, emphasizing the need for new therapies (Hofbauer et al., 2007).

In the last decade, ghrelin, a hormone secreted predominantly from the stomach, has attracted much attention due to its orexigenic effects as well as its function in mediating body weight gain and adiposity, demonstrated both in humans and rodents (Nakazato et al., 2001, Sangiao-Alvarellos et al., 2009, Theander-Carrillo et al., 2006, Tschop et al., 2000, Wren et al., 2001a and Wren et al., 2001b). Ghrelin circulates in the bloodstream in two different forms: acylated (AG) and unacylated (UAG). AG has a unique feature: a posttranslational esterification of a fatty acid (n-octanoic or, to a lesser extent, $n$ decanoic) on serine at position three. It acts as the endogenous ligand of the growth hormone secretagogue receptor (GHSR) ( Kojima et al., 1999, Kojima et al., 2001a, Kojima et al., $2001 \mathrm{~b}$ and Nakazato et al., 2001) and its acylation is considered necessary for its actions via GHSR1a (the functional variant of GHSR) ( Howard et al., 1996 and Kojima et al., 1999). Recently, several groups identified ghrelin O-acyltransferase (GOAT), a membrane-bound enzyme that transfers octanoate from octanoyl CoA to serine-3 of ghrelin, forming an acyl ester ( Gutierrez et al., 2008 and Yang et al., 2008) and a recent study observed that GOAT links dietary lipids with the endocrine control of energy balance ( Kirchner et al., 2009). 
Despite much pharmacological data, the evidence for a physiological role of ghrelin in the control of appetite is still less clear. Mice with targeted deletions in either the gene for ghrelin or the GHSR as well as transgenic models exhibit an essentially normal metabolic phenotype when fed a regular chow diet, suggesting ghrelin may have a redundant role in the regulation of food intake (Ariyasu et al., 2005, Asakawa et al., 2005, Iwakura et al., 2005, Longo et al., 2008, Pfluger et al., 2008, Sun et al., 2003, Sun et al., 2006 and Sun et al., 2008). Nevertheless, the current body of evidence implicates ghrelin to play an important role in the control of glucose and lipid homeostasis (Broglio et al., 2001, Broglio et al., 2003, Vestergaard et al., 2008a, Vestergaard et al., 2008b and Zhao et al., 2010).

Several studies show that treatment with ghrelin induces hyperglycemia and reduces insulin secretion (Broglio et al., 2001 and Cui et al., 2008). Moreover, it was found that a relation between ghrelin levels and insulin resistance exists (Gauna et al., 2004, Pacifico et al., 2009 and Vestergaard et al., 2008b). Altered plasma ghrelin levels are associated with insulin resistance in healthy, overweight and obese humans, and are thought to contribute to the association of insulin resistance and metabolic syndrome (Pacifico et al., 2009, St-Pierre et al., 2007 and Yada et al., 2008).

Furthermore, ghrelin administration induces lipid storage and synthesis by promoting mRNA expression of fat storage-promoting enzymes in white adipose tissue (WAT) and liver, such as lipoprotein lipase (LPL), acetyl-CoA carboxylase alpha (ACC $\alpha$ ), fatty acid synthase (FAS), and stearoyl-CoA desaturase-1 (SCD-1). In contrast, ghrelin inhibits lipid oxidation, decreasing activity and gene expression of the liver isoform of carnitine palmitoyltransferase 1 (CPT1A) (Barazzoni et al., 2005, SangiaoAlvarellos et al., 2009 and Theander-Carrillo et al., 2006).

These findings and the observations that circulating ghrelin levels are increased prior to a meal and during food deprivation and caloric restriction, as well as in disease states such as anorexia and cachexia, but reduced after a meal and in obesity (Ikezaki et al., 2002, Liu et al., 2008, Shiiya et al., 2002, Tschop et al., 2001a, Tschop et al., 2001b, Van der Lely et al., 2004 and Yang et al., 2007), strongly implicate ghrelin being involved in the regulatory processes controlling meal initiation, priming metabolic pathways and leading to more efficient calorie storage.

The aim of this study was to block acyl-ghrelin in order to investigate the metabolic adjustments during the fasting-refeeding cycle on glucose and lipid metabolism in the liver, the principal tissue of intermediary metabolism. Protein and mRNA levels as well as enzyme activities of the main enzymes involved in glucose and lipid metabolism were assessed. The neutralization of AG was accomplished by using the compound NOX-B11(2), an 1-RNA-based antagonist (also called a Spiegelmer) of ghrelin. NOX-B11(2) does not interact with the ghrelin receptor, but is highly specifically binding the bioactive $n$ octanoylated form of ghrelin itself. Moreover this compound neutralizes other types of acylated ghrelin like decanoyl-ghrelin (data not show, decenoyl-ghrelin was not tested). It blocks the biological effect by preventing ghrelin's activation of the endogenous receptor ( Helmling et al., 2004). The effects of ghrelin neutralization with NOX-B11(2) and related compounds on growth hormone secretion, food intake and body weight gain in diet-induced obese mice were previously demonstrated ( Helmling et al., 2004, Kobelt et al., 2006 and Shearman et al., 2006).

Our data suggest that ghrelin has an essential role in body weight recovery after prolonged fasting. Moreover, neutralization of ghrelin impairs the normal decrease in lipogenic and glycolytic enzymes in the liver during fasting. Upon availability of food following a fasting period, the recovery of energetic reserves and metabolic pathways is compromised when ghrelin is neutralized.

\section{Materials and methods}

\subsection{Animals and compounds}

All experiments and animal protocols involved in this study were reviewed and approved by the Ethics Committees of the UDC and CHUAC, in accordance with EU Normative for the use of experimental animals. Male Wistar rats (2-3 months old; body weight: $378 \pm 5 \mathrm{~g}$ ) were housed in a temperature controlled room, with a $12 \mathrm{~h}$ light, $12 \mathrm{~h}$ dark cycle (lights from 08:00 to 20:00 h). All rats were provided with ad libitum access to water.

Acyl-ghrelin was purchased from Bachem (Bachem, Switzerland). Spiegelmer (SPM) NOX-B11(2) and the non-functional control SPM were synthesized at NOXXON Pharma AG using standard phosphoramidite chemistry. NOX-B11(2) is a derivative of SPM NOX-B11 whose selection has been described previously (Helmling et al., 2004). It was designed to bind specifically to acylated (bioactive) ghrelin, thus preventing the hormone from activating the GHSR1a (Helmling et al., 2004 and Shearman et al., 2006). 
2.2. Effects of acute ghrelin treatment on food intake in animals treated with anti ghrelin SPM NOX$B 11(2)$

To study the efficacy of NOX-B11(2) counteracting acyl-ghrelin, male Wistar rats fed ad libitum were intraperitoneally (IP) injected with vehicle (saline, $n=7$ ), NOX-B11(2) (15 or $30 \mathrm{mg} / \mathrm{kg}, n=7$ ), or control SPM $(30 \mathrm{mg} / \mathrm{kg}, n=7)$ at 9:00 a.m. Two hours later, at 11:00 a.m. the animals were injected with saline or ghrelin $(25 \mu \mathrm{g} / \mathrm{rat}, \mathrm{IP})$. Cumulative food intake was measured $2 \mathrm{~h}$ after treatment at 1:00 p.m.

\subsection{Fasting and fasting-refeeding trials}

In order to clarify the influence of acyl-ghrelin neutralization on hepatic glucose and lipid metabolism during the fasting-refeeding cycle, rats were fasted for $48 \mathrm{~h}$ or fasted and refed for $24 \mathrm{~h}$ or $48 \mathrm{~h}$. Every $24 \mathrm{~h}$ animals (eight rats per group) were injected intraperitoneally with NOX-B11(2) (30 mg/kg, IP) or control SPM $(30 \mathrm{mg} / \mathrm{kg}$, IP). The first injection was given once food had been removed. During the refeeding period, food was restricted to $80 \%$ of the daily amount of food ingested by the animals when given ad libitum access. Food was provided daily and both groups ate all the food offered. This refeeding regimen was chosen as it was expected to lead to a more pronounced effect, if ghrelin neutralization affects the utilization of nutrients. The regimen of treatment is illustrated in Fig. 1.
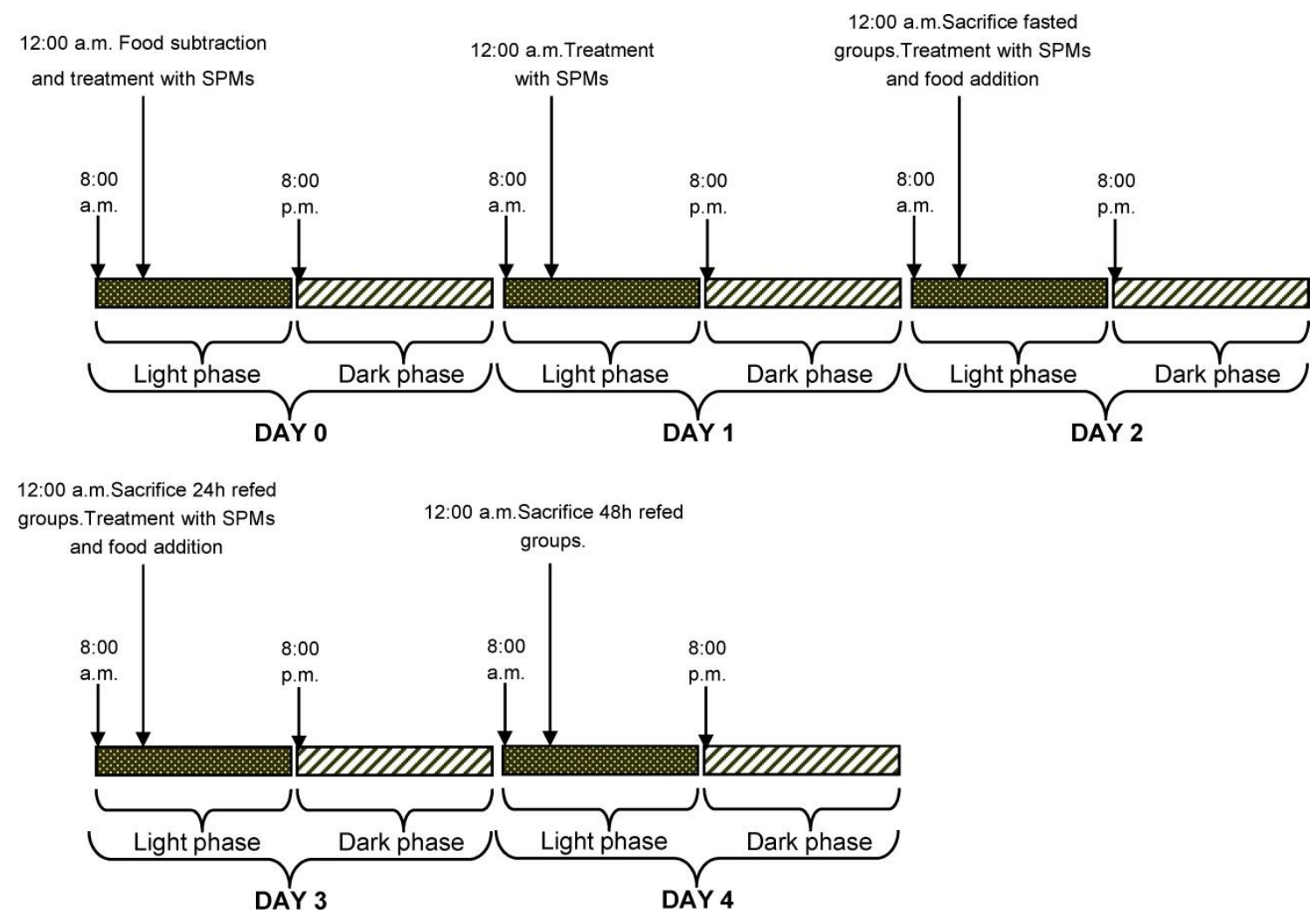

Fig. 1. Schematic representation of treatments of the animals.

Rats were sacrificed by cervical dislocation and trunk blood was extracted. Livers were dissected, divided in parts, and stored at $-80{ }^{\circ} \mathrm{C}$ until further processing or homogenized with a motor pestle in icecold buffer containing $50 \mathrm{mM}$ Tris- $\mathrm{HCl}$ (pH 7.4), $250 \mathrm{mM}$ sucrose, $1 \mathrm{mM}$ ethylenediaminetetraacetic acid, $1 \mathrm{mM}$ dithiothreitol, $100 \mathrm{mM} \mathrm{NaF}$ and protease inhibitor cocktail (Roche). Subsequently, homogenates were centrifuged for $10 \mathrm{~min}$ at $3000 \mathrm{rpm}$ and the supernatant was extracted and used for studies of CPT1 activity. 


\subsection{Plasma measurements}

Insulin levels were measured by a commercially available radioimmunoassay (Linco Research Inc.) according to the manufacturer's specifications. Plasma acyl-ghrelin levels were measured by ELISA according to the manufacturer's instructions (Millipore). Plasma glucose, lactate and triglyceride levels were assessed using a commercial kit based on a colorimetric method (Glucose, lactate and Triglyceride Spinreact). Plasma GH concentrations were determined by double antibody RIA using materials supplied by the National Hormone Pituitary Program, as described previously (Seoane et al., 2004).

\subsection{Real-time quantitative PCR}

mRNA levels of ACC $\alpha$, FAS, SCD-1 and CPT1A were studied by real-time PCR (Roche) using specific primers and probes (Table 1). All reactions were carried out using the following cycling parameters: $50{ }^{\circ} \mathrm{C}$ for $2 \mathrm{~min}, 95^{\circ} \mathrm{C}$ for $10 \mathrm{~min}$ followed by 40 cycles of $95^{\circ} \mathrm{C}$ for $15 \mathrm{~s}$ and $60{ }^{\circ} \mathrm{C}$ for $1 \mathrm{~min}$. For data analysis, the input value of the target gene was standardized to the $18 \mathrm{~S}$ value for each sample. Data were expressed in comparison with the average value for the fed rats.

Table 1. Primer sequences used for real-time PCR.

\begin{tabular}{|c|c|c|c|}
\hline \multirow[t]{2}{*}{$\mathrm{ACC} \alpha$} & NM_022193 & Forward & 5'-TGGGCGGGATGGTCTCTTT-3' \\
\hline & & Probe & FAM-5'-ACCTTTGAAGATTTCGTCAGGATCTTTGATGA-3'-TAMRA \\
\hline \multirow[t]{2}{*}{ FAS } & NM_017332 & Forward & 5'-GACATTTCATCAGGCCACC-3' \\
\hline & & Reverse & 5'-CCTCTAGCAGCCGCACCTC-3' \\
\hline \multirow[t]{3}{*}{ SCD-1 } & NM_139192.2 & Forward & 5'-TGCCAGAGGGAATAGGGAAA-3' \\
\hline & & Reverse & 5'- СТСТСССАТССТТАСТТАСАAАССА-3' \\
\hline & & Probe & FAM-5'-TCACCTTGAGAGAAGAATTAGCACGCACGG-3'-TAMRA \\
\hline \multirow[t]{3}{*}{ CPT1A } & NM_031559 & Forward & 5'-ATGACGGCTATGGTGTCTCC -3' \\
\hline & & Reverse & 5'-TCATGGCTTGTCTCAAGTGC -3' \\
\hline & & Probe & FAM-5'-TGAGACAGACTCAGACCGCT-3'-TAMRA \\
\hline
\end{tabular}

\subsection{Western blotting}

Liver samples were homogenized in 10 volumes ice-cold buffer containing $50 \mathrm{mM}$ Tris- $\mathrm{HCl}(\mathrm{pH} 7.4)$, $250 \mathrm{mM}$ sucrose, $1 \mathrm{mM}$ EDTA, $1 \mathrm{mM}$ DTT, $100 \mathrm{mM} \mathrm{NaF}$ and protease inhibitor cocktail (Roche). For each sample, total protein lysates from liver $(20 \mu \mathrm{g})$ were subjected to SDS-PAGE, electrotransferred on a polyvinylidene difluoride membrane and probed with the indicated antibodies: ACC $\alpha$ and phosphoACC $\alpha$ Ser79 (pACC $\alpha)$; 5'AMP-activated protein kinase alpha (AMPK $\alpha$ ) and phosphoAMPK $\alpha$-Thr172 $(\mathrm{pAMPK} \alpha)(\mathrm{Upstate})$; total serine/threonine kinase protein kinase B (AKT) and phospho AKT (pAKT) (Cell Signaling); $\beta$-actin (Sigma); FAS and CPT1A (Santa Cruz Biotechnology). For protein detection we used horseradish peroxidase-conjugated secondary antibodies and bands were visualized by enhanced chemiluminescence as instructed by the manufacturer (Amersham Biosciences). For quantification we applied ImageJ software based analysis (http://rsb.info.nih.gov/ij/). Protein levels were normalized to $\beta$ actin for each sample.

\subsection{Enzyme and glycogen assays}

With the exception of CPT1 activity, which was analyzed in fresh tissue, all enzymatic assays were carried out with liver supernatants that were prepared as described above for Western blot assays. The reactions were started by the addition of homogenates $(30 \mu \mathrm{l})$ and substrates $(20 \mu \mathrm{l}$, omitted in controls) to the reaction mixture (final volume $250 \mu \mathrm{l}$ ), and the reactions were incubated at $37{ }^{\circ} \mathrm{C}$ for pre-established times (5-15 min). Enzyme activities were determined by spectrophotometry using a microplate reader (Tecan). FAS (Saggerson and Greenbaum, 1970), glucose-6-phosphate dehydrogenase (G6PDH), 6- 
phosphogluconate dehydrogenase (6PGDH) (Tian et al., 1998 and Tian et al., 1999), CPT1 (Karlic et al., 2002 and Shin et al., 2006), ATP citrate lyase (ACL) (Corrigan and Rider, 1983), glucokinase (GK), hexokinase (HK) (Davidson and Arion, 1987), fructose bisphosphatase (FBase) (Westbury and Hahn, 1984) and pyruvate kinase (PK) (Denton et al., 1979) activities were measured using methods previously described. Glycogen levels in the liver extracts were determined as described by Keppler and Decker (1974).

\subsection{Statistical analysis}

Data are expressed as percentage of fed rats (control group) and presented as mean \pm SEM and analyzed using SigmaStat 3.1 (Systat software, Inc.). Statistical significance was determined by one-way ANOVA with post hoc Student-Newman-Keuls test. $p<0.05$ was considered significant. Different letters above bars indicate statistical significance.

\section{Results}

\subsection{SPM NOX-B11(2) inhibits orexigenic effects of ghrelin}

In order to test the efficacy of NOX-B11(2) in neutralizing ghrelin's effect on food intake, we treated rats with Spiegelmer and AG as described under Section 2. As expected, pre-treatment with NOX-B11(2) blocked ghrelin-stimulated food intake, whereas the non-binding control SPM did not affect food intake induced by ghrelin (Fig. 2). Neither NOX-B11(2) nor control SPM altered food intake compared with animals treated with saline when administered without exogenous AG (data not shown).

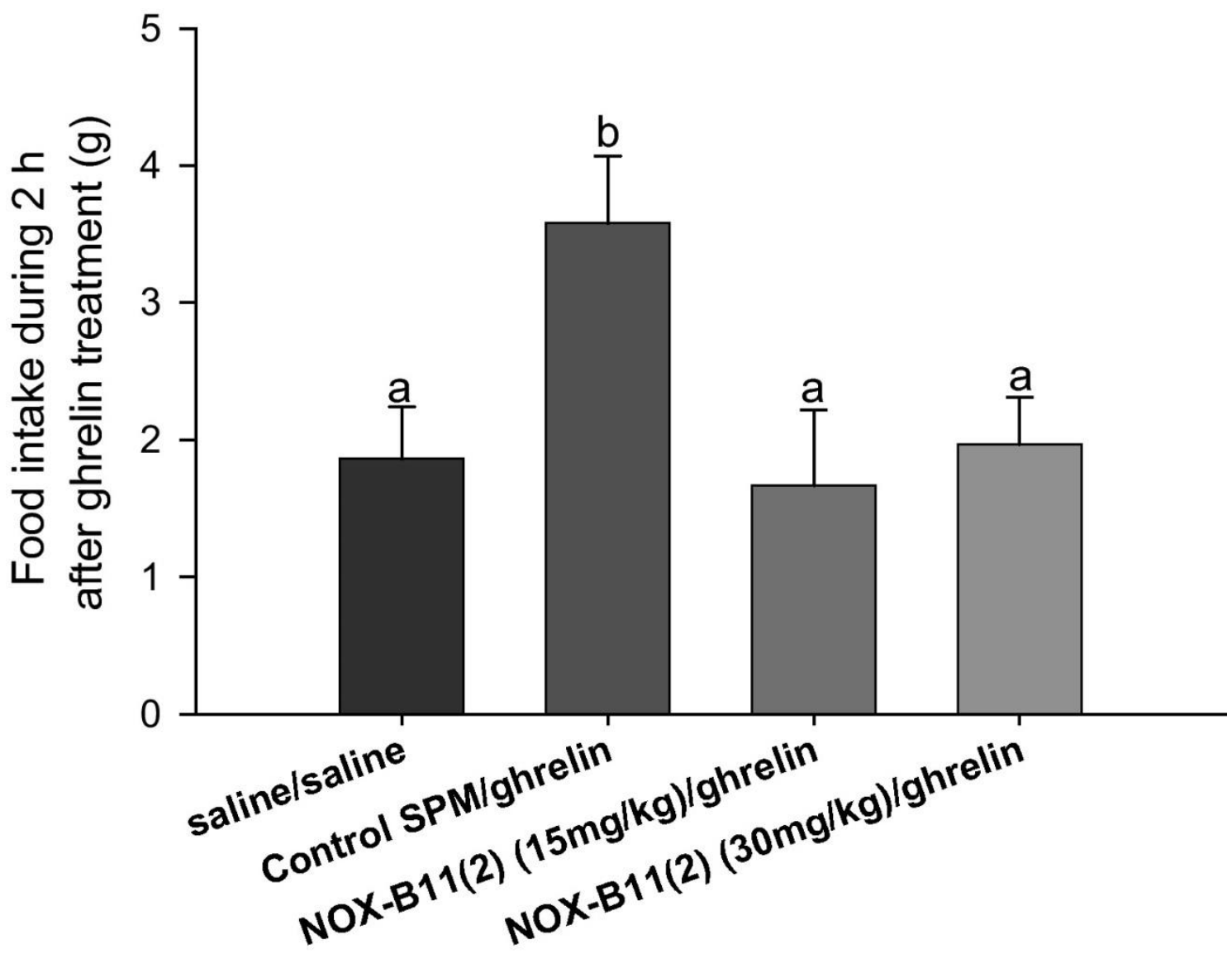

Fig. 2. Effect of an IP ghrelin treatment on cumulative food intake during $2 \mathrm{~h}$ following injection in rats (seven animals per group) treated previously with non-functional control SPM or NOX-B11(2). Values are expressed as mean \pm SEM. Different letters indicate statistical significance $(p<0.05)$. 


\subsection{Effect of NOX-B11(2) on body weight during fasting-refeeding cycle}

To determine the effects of ghrelin neutralization during refeeding rats were fasted and refed with or without treatment with NOX-B11(2) as described in Section 2 and body weight changes were recorded (Fig. 3). Body weight (BW) loss induced by fasting was unaffected by the neutralization of ghrelin. In contrast, treatment with NOX-B11(2) exerted a strong effect on the recovery of weight loss during the refeeding period. Animals treated with control Spiegelmer began to regain body weight $24 \mathrm{~h}$ after refeeding and this process continued until $48 \mathrm{~h}$. In contrast, rats treated with NOX-B11(2) did not recover corporal weight after the refeeding until $48 \mathrm{~h}$. This effect was not related to an inhibition of appetite as both treatment groups ingested all the food offered during the refeeding period. Thus, the inhibitory effect of NOX-B11(2) on body weight recuperation during refeeding following a $48 \mathrm{~h}$ period of food deprivation appears to be independent of food intake.

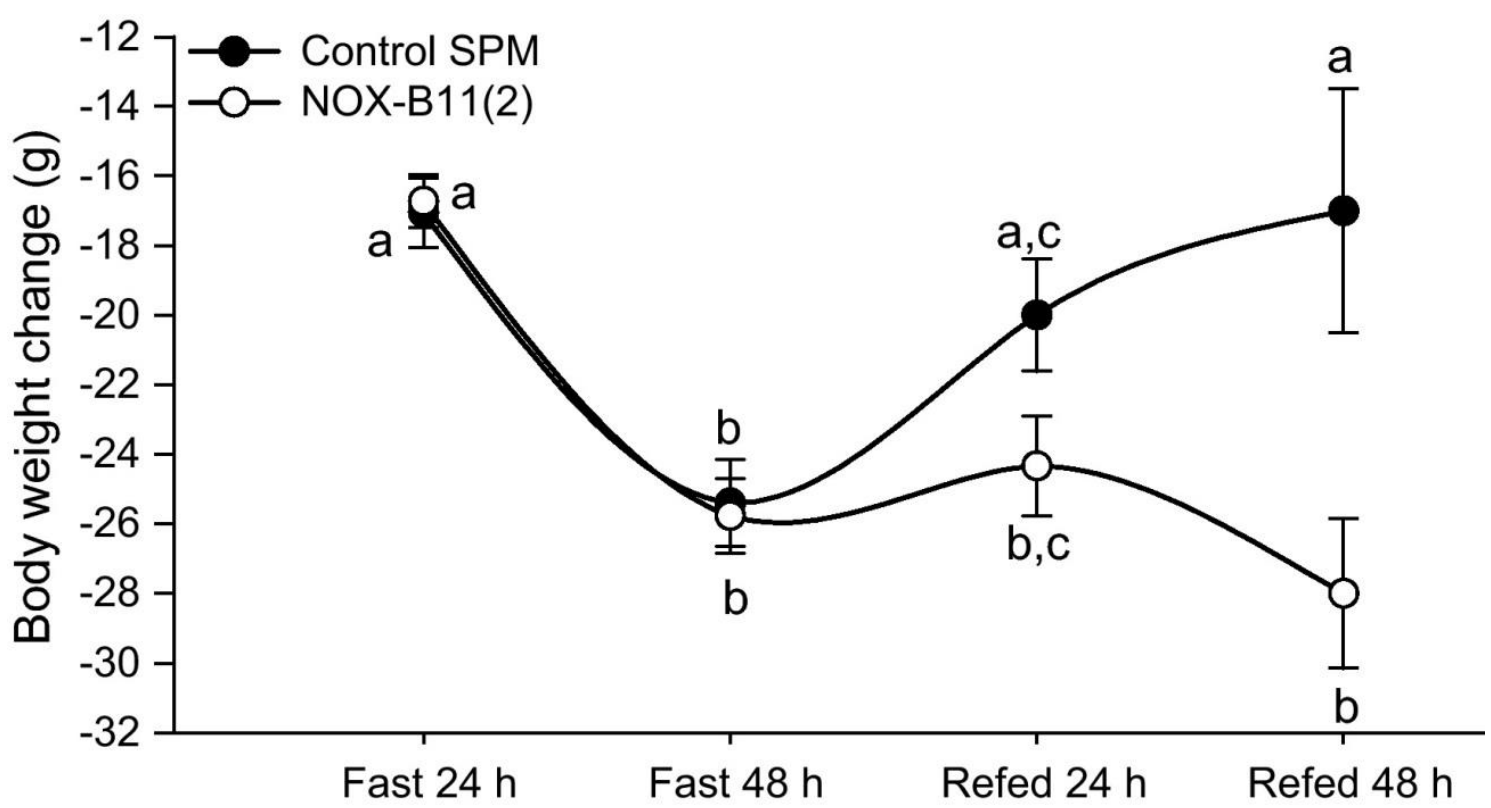

Fig. 3. Effect of ghrelin neutralization on body weight change in fasted ( $48 \mathrm{~h})$ and fasted (48 h)-refed (24 or $48 \mathrm{~h})$ rats. Values are means \pm SEM of eight animals per group. Different letters indicate statistical significance $(p<0.05)$.

\subsection{Effects of ghrelin neutralization during fasting-refeeding cycle on plasma parameters}

In order to further analyze the effects of ghrelin neutralization, various plasma parameters were examined (Fig. 4). As expected, $48 \mathrm{~h}$ after fasting plasma AG levels had increased significantly in rats treated with control SPM compared to the fed group. The AG levels decreased during refeeding, but did not return to the initial levels during the $48 \mathrm{~h}$ refeeding period. In rats treated with NOX-B11(2), fasting led to an even larger increase of $\mathrm{AG}$ levels and the increase did not diminish during the refeeding period (Fig. 4A). The tremendous increase in AG levels in animals treated with NOX-B11(2) is likely due to the presence of circulating AG-Spiegelmer complexes that are cleared more slowly, a finding that was reported previously (Shearman et al., 2006) and is typical for a drug binding to a ligand. 

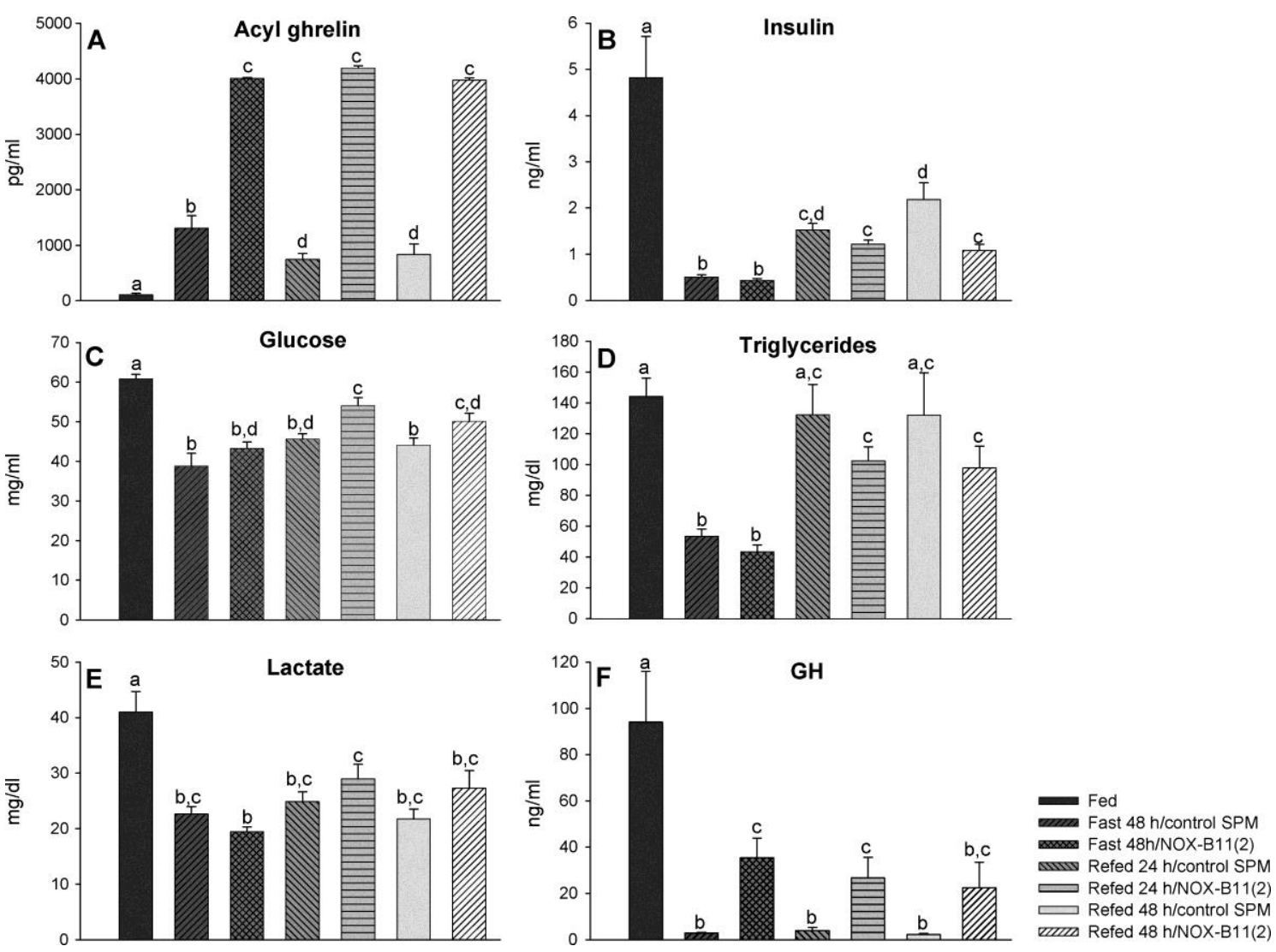

Fig. 4. Plasma levels of acyl-ghrelin, insulin, glucose, triglycerides, lactate and GH in fed, fasted (48 h) and fasted (48 h)-refed (24 or $48 \mathrm{~h}$ ) rats treated with NOX-B11(2) or non-functional control SPM. Values are means \pm SEM of eight animals per group. Different letters indicate statistical significance $(p<0.05)$.

Plasma insulin levels decreased equally in both groups following fasting. However, after refeeding insulin levels in animals treated with NOX-B11(2) were lower than in animals injected with control SPM (Fig. 4B). Similarly, plasma glucose levels were decreased after fasting in both Spiegelmer treatment groups. During refeeding, only in the animals treated with NOX-B11(2) a significant increase in plasma glucose levels was observed (Fig. 4C). In both groups glucose and insulin levels remained significantly below the levels of fed animals and we believe that this fact is for the feeding regimen, since after $48 \mathrm{~h}$ of fasting the animals were subjected to caloric restriction.

After $48 \mathrm{~h}$ of fasting, triglyceride (Fig. 4D) and lactate levels (Fig. 4E) were decreased in both experimental groups. During the refeeding period, plasma triglyceride levels in animals treated with control SPM recovered the values of fed rats within $24 \mathrm{~h}$, while those treated with NOX-B11(2) remained lower even after $48 \mathrm{~h}$ of refeeding (Fig. 4D). Lactate levels increased slightly during the refeeding period in rats treated with NOX-B11(2) only (Fig. 4E), but the fasting-induced decline in lactate levels was not reversed in either treatment group during the refeeding period. As expected, $48 \mathrm{~h}$ after fasting plasma $\mathrm{GH}$ levels had decreased significantly in rats treated with control SPM and NOX-B11(2) compared to the fed group, however the decrease was lower in animals treated with NOX-B11(2). During the refeeding period, either group recovered the values of fed rats but those treated with NOX-B11(2) remained higher compared to control group even after $48 \mathrm{~h}$ of refeeding (Fig. 4F).

\subsection{Effects of ghrelin neutralization during fasting and refeeding cycle on liver glucose metabolism}

To assess the effect of AG neutralization during the fasting-refeeding cycle on glucose metabolism we analyzed the activity levels of enzymes involved in glucose metabolism. The results for several key enzymes of the glycolytic pathway are shown in Fig. 5A-C. Food deprivation clearly diminished activity levels of GK (Fig. 5A), HK (Fig. 5B) and PK (Fig. 5C). Activity levels of GK were strongly reduced following fasting in both experimental groups. After $24 \mathrm{~h}$ of refeeding the recovery of GK activity was similar in animals treated with NOX-B11(2) and control Spiegelmer. However, while GK activity in the 
NOX-B11(2) group returned to the level of fed animals after $48 \mathrm{~h}$ of refeeding, it did not recover in the control group (Fig. 5A). Activity levels of HK (Fig. 5B) and PK (Fig. 5C) were reduced following fasting in both animals treated with NOX-B11(2) and animals treated with control SPM. Following fasting there was significantly higher HK and PK activity for the NOX-B11(2) treatment group than the control Spiegelmer group, suggesting that ghrelin neutralization may have some protective effect on the activity of these enzymes during fasting. This effect disappeared during refeeding. No differences in HK and PK activities between control and NOX-B11(2) groups were observed following refeeding and the activity levels remained significantly below the levels of fed animals.
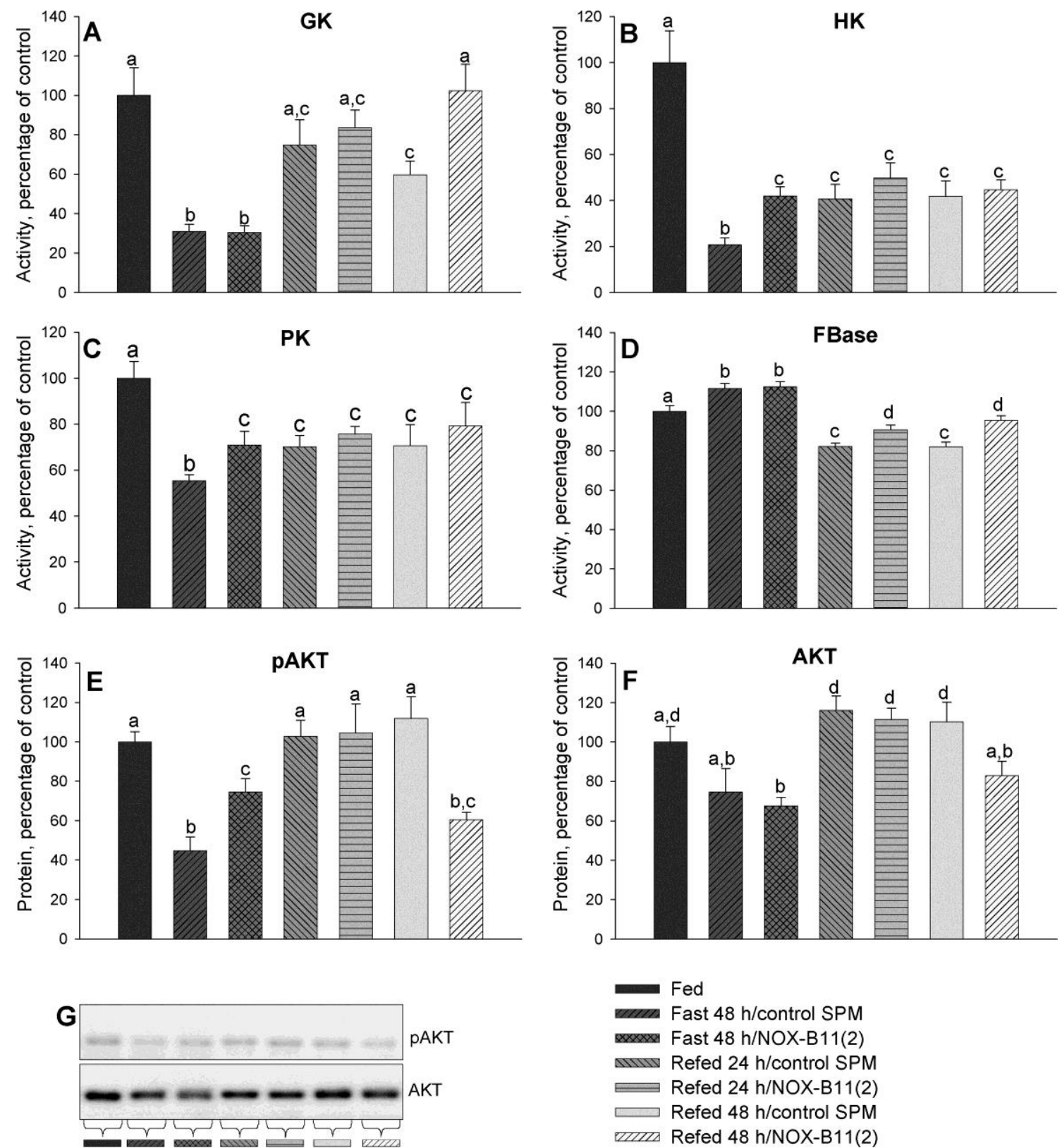

Fig. 5. Hepatic activity levels of glucokinase (GK), hexokinase (HK), pyruvate kinase (PK), fructose bisphosphatase (Fbase) (A-D) and protein levels of total serine/threonine kinase protein kinase B AKT and pAKT (E-G) in fed, fasted (48 h) and fasted (48 h)refed $(24$ or $48 \mathrm{~h})$ rats treated with NOX-B11(2) or control non-functional SPM. Values are means \pm SEM of eight animals per group. Different letters indicate statistical significance $(p<0.05)$. 
Activity levels of FBPase (Fig. 5D), a key enzyme of gluconeogenesis, increased significantly during fasting in both experimental groups and diminished during refeeding. FBase activity during refeeding was moderately (but significantly) higher in animals in which ghrelin was neutralized. This suggests that ghrelin neutralization impairs the normal response of FBase activity during refeeding following fasting (Fig. 5D).

Several studies relate the effects of ghrelin to changes in protein levels of serine/threonine kinase protein kinase B (AKT) and pAKT (Fig. 5E-G) (Baldanzi et al., 2002, Barazzoni et al., 2007, Chung et al., 2008 and Rossi et al., 2008). Moreover, in the liver, insulin controls both lipid and glucose metabolism through its cell surface receptor and intracellular mediators such as phosphatidylinositol 3kinase and serine-threonine kinase AKT. We observed that fasting caused a decrease in protein levels of phospho- (active) and total-AKT (Fig. 5E-G). Interestingly, after $48 \mathrm{~h}$ fasting the levels of pAKT were significantly less reduced in rats treated with NOX-B11(2), whereas reduction of total AKT levels was the same. In animals treated with the inactive control Spiegelmer both pAKT- and AKT-levels recovered to reach the levels of fed animals after $24 \mathrm{~h}$ of refeeding and these values did not change after $48 \mathrm{~h}$ of refeeding. In animals treated with NOX-B11(2) pAKT- and AKT-levels recovered to those of fed animals after $24 \mathrm{~h}$ of refeeding, but they decreased again after $48 \mathrm{~h}$ refeeding.

To further investigate the role of AG during fasting and refeeding on hepatic glycemic reserves, glycogen levels were assessed (Fig. 6). The neutralization of AG did not affect the decrease in hepatic glycogen levels during fasting. However, after 24 and $48 \mathrm{~h}$ of refeeding, glycogen levels were lower in NOX-B11(2) treated animals compared with their controls.

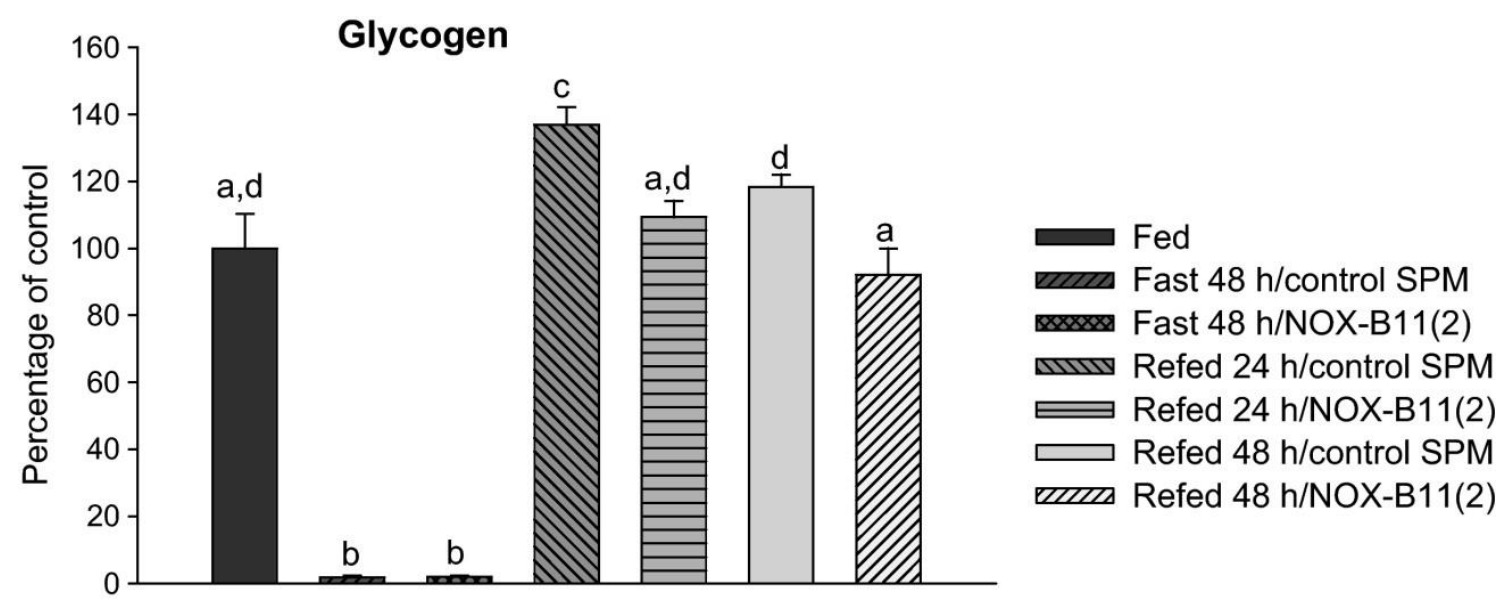

Fig. 6. Hepatic glycogen levels in fed, fasted $(48 \mathrm{~h})$ and fasted $(48 \mathrm{~h})$-refed ( 24 or $48 \mathrm{~h})$ rats treated with NOX-B11(2) or nonfunctional control SPM. Values are means \pm SEM of eight animals per group. Different letters indicate statistical significance $(p<0.05)$.

3.5. Effects of ghrelin neutralization during fasting-refeeding cycle on the hepatic lipogenic pathway and the pentose phosphate pathway

In order examine ghrelin function on hepatic lipogenesis during a fed-fasted-refed cycle, mRNA, protein and activity levels of enzymes involved in lipid synthesis were assessed in the different treatment groups. The levels of mRNA, protein and enzymatic activity of key enzymes involved in the regulation of lipid metabolism in liver are shown in Fig. 7. As expected, fasting markedly diminished mRNA levels of the fat storage promoting enzymes such as FAS, SCD-1, and ACC $\alpha$ in all animals, whether treated with NOX-B11(2) or not. However, after $24 \mathrm{~h}$ of refeeding, these enzymes' expression increased to a greater extent in animals in which AG was not neutralized (Fig. 7A-C). Similarly, protein levels of FAS, ACC $\alpha$ and pACC $\alpha$ (Fig. 7D-F and I), and activity levels of FAS (Fig. 7J) and ACL (Fig. 7K) also decreased during fasting, but this decrease was less pronounced in animals treated with NOX-B11(2). Moreover, after $24 \mathrm{~h}$ of refeeding protein levels of FAS and ACC $\alpha$ and activity levels of FAS and ACL significantly increased in the control group over fasted animals, but not in the NOX-B11(2) group. However these enzymes (mRNA, protein or activity) did not show any differences between control group and animals treated with NOX-B11(2) after $48 \mathrm{~h}$ of refeeding. 

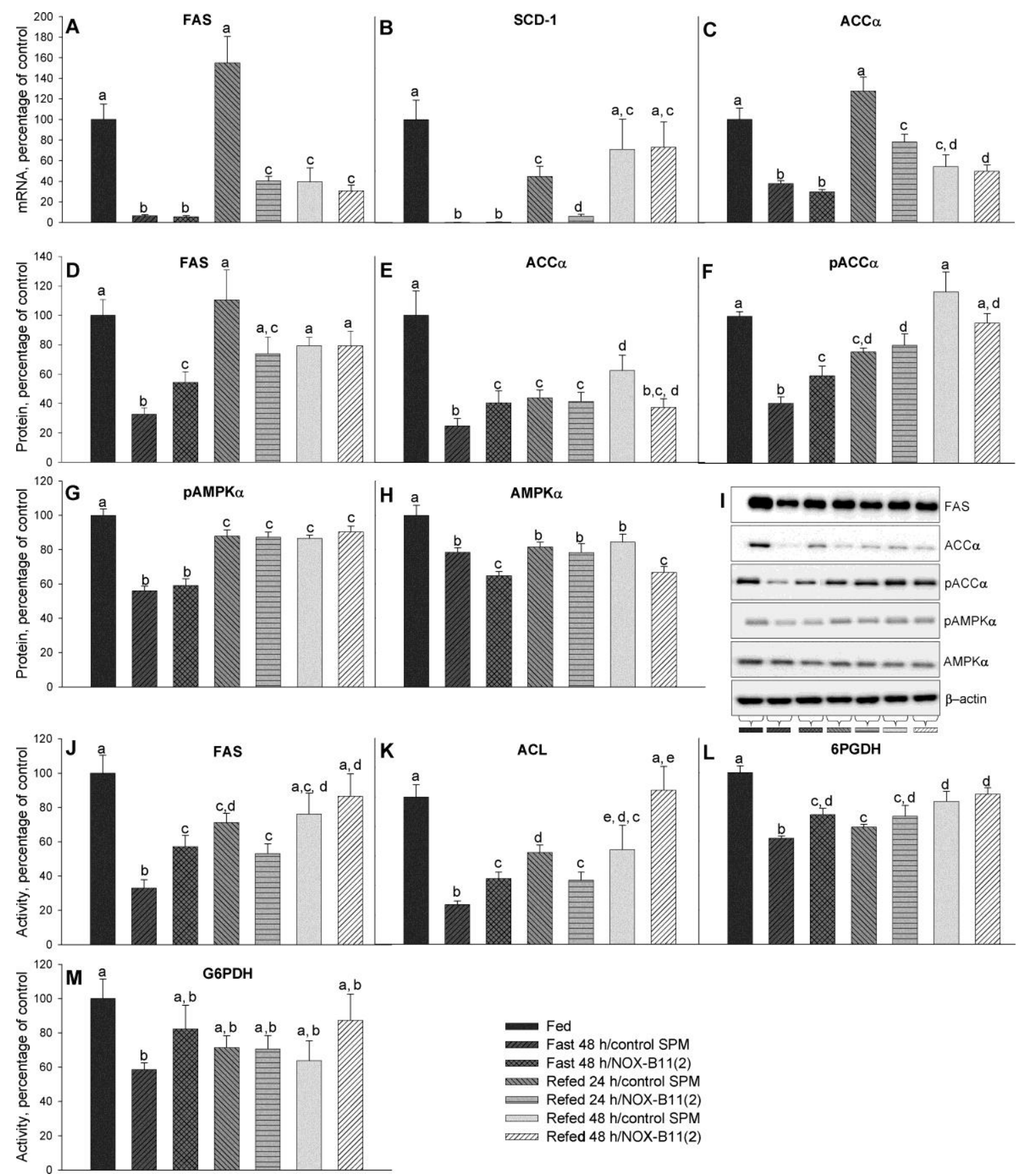

Fig. 7. Hepatic mRNA (A-C), protein (D-I) and activity levels (K-M) of lipid metabolism-related enzymes in fed, fasted (48 h) and fasted $(48 \mathrm{~h})$-refed $(24$ or $48 \mathrm{~h})$ rats treated with NOX-B11(2) or non-functional control SPM. Values are means \pm SEM of eight animals per group. Different letters indicate statistical significance $(p<0.05)$.

After $48 \mathrm{~h}$ of fasting, protein levels of pAMPK $\alpha$ and AMPK $\alpha$ (Fig. 7G-I) were significantly diminished in both groups. The decrease in AMPK $\alpha$ was lower in animals treated with NOX-B11(2) compared with the control group. $48 \mathrm{~h}$ after refeeding, protein levels of total AMPK $\alpha$ were further decreased in NOX-B11(2) treated animals.

Fatty acid synthesis requires NADPH. It is produced by malic enzyme (ME) and via the pentose phosphate pathway by activation of G6PDH and 6PGDH. Interestingly, after $48 \mathrm{~h}$ of fasting, the enzymatic activities of G6PDH and 6PGDH exhibited a greater decrease in the animals treated with SPM control compared with those treated with NOX-B11(2). After $24 \mathrm{~h}$ of refeeding only the activity of 6PGDH in control animals increased significantly (Fig. 7L and M).

Overall, these data suggest a role of AG in hepatic inhibition/restoration of lipogenesis during fasting and refeeding cycle. 


\subsection{Effects of ghrelin neutralization during fasting and refeeding cycle on liver $\beta$-oxidation}

We next examined levels of mRNA, protein and activity of CPT1A, an enzyme involved in lipid oxidation. The levels of mRNA for CPT1A increased during fasting and decreased with refeeding in both treatment groups. In animals treated with NOX-B11(2) the decrease of CPT1A mRNA levels appeared to recover more slowly during the first $24 \mathrm{~h}$ of refeeding compared to the control group, but both treatment groups exhibited the same levels after $48 \mathrm{~h}$ of refeeding (Fig. 8A). Protein levels of CPT1A decreased in fasted animals and recovered the values of the fed state after $24 \mathrm{~h}$ of refeeding in both treatment groups (Fig. 8B). Activity levels of CPT1A increased during fasting, independent of treatment. This increase persisted during the first $24 \mathrm{~h}$ of refeeding, but returned to the activity level of fed animals after $48 \mathrm{~h}$ of refeeding.
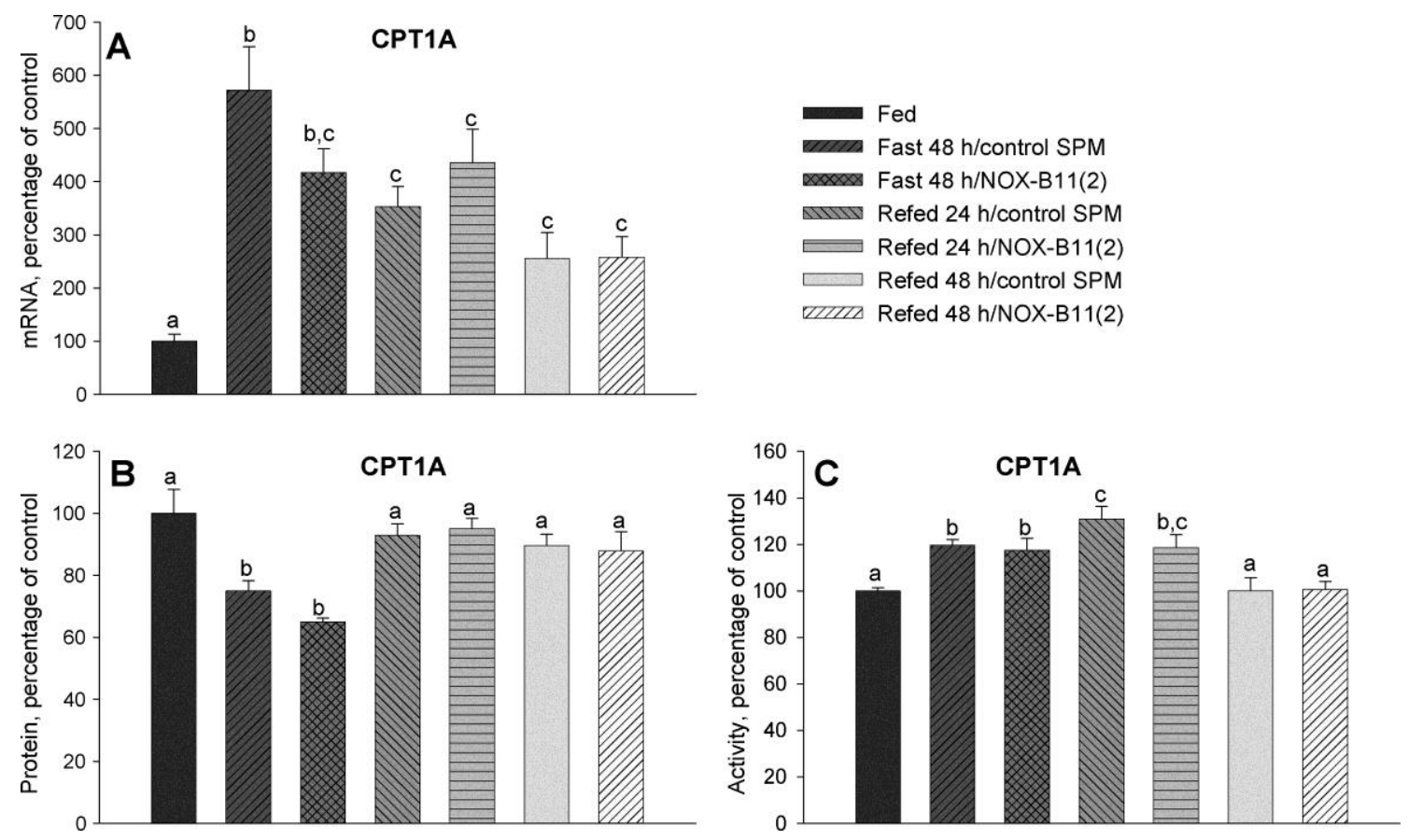

Fig. 8. Hepatic mRNA (A), protein (B) and activity levels (E) of CPT1A, $\beta$-oxidation-related enzyme in fed, fasted (48 h) and fasted $(48 \mathrm{~h})$-refed $(24$ or $48 \mathrm{~h})$ rats treated with NOX-B11(2) or non-functional control SPM. Values are means \pm SEM of eight animals per group. Different letters indicate statistical significance $(p<0.05)$.

\section{Discussion}

Our results provide a clear indication that ghrelin neutralization during the fasting-refeeding cycle impairs body weight recuperation and alters hepatic glucose and lipid metabolism.

Since its identification ghrelin has received much attention due to its orexigenic and adipogenic effects, both in rodents and humans (Tschop et al., 2000 and Wren et al., 2001a). However, the observations that transgenic models and ghrelin knockout animals exhibit normal metabolic phenotypes make it difficult to pinpoint ghrelin's exact role in the control of appetite and body weight (Ariyasu et al., 2005, Asakawa et al., 2005, Iwakura et al., 2005, Longo et al., 2008, Pfluger et al., 2008, Sun et al., 2003, Sun et al., 2006 and Sun et al., 2008). The findings that ghrelin levels are increased before food intake, during caloric restriction, body weight loss or anorexia, but decreased after food intake and obesity (Cummings et al., 2001, Cummings et al., 2002 and Shiiya et al., 2002) are in agreement with the hypothesis for ghrelin being part of a mechanism by which the organism senses changes in nutrient availability and triggers biological responses that modulate the efficiency of energy storage during periods of overflow or scarcity of nutrients. Such a model is supported by the observation that treatment with exogenous ghrelin increases expression and protein levels of lipogenic enzymes independently of any orexigenic effects (Theander-Carrillo et al., 2006).

To test the hypothesis mentioned above, we analyzed if ghrelin neutralization during the fastingrefeeding cycle alters metabolic pathways and energy storage in the liver. The main form of energy 
storage in liver is represented by glycogen and lipids. The origin of the stored lipids can be either the diet or de novo synthesis from carbohydrate through lipogenesis. Therefore, the major function of glycolysis in the liver is to provide the necessary glucose metabolites for de novo lipid synthesis (Foufelle and Ferre, 2002). The effects of ghrelin neutralization on enzymes involved in glycolysis and lipogenesis (summarized in Fig. 9) were analyzed in this study.

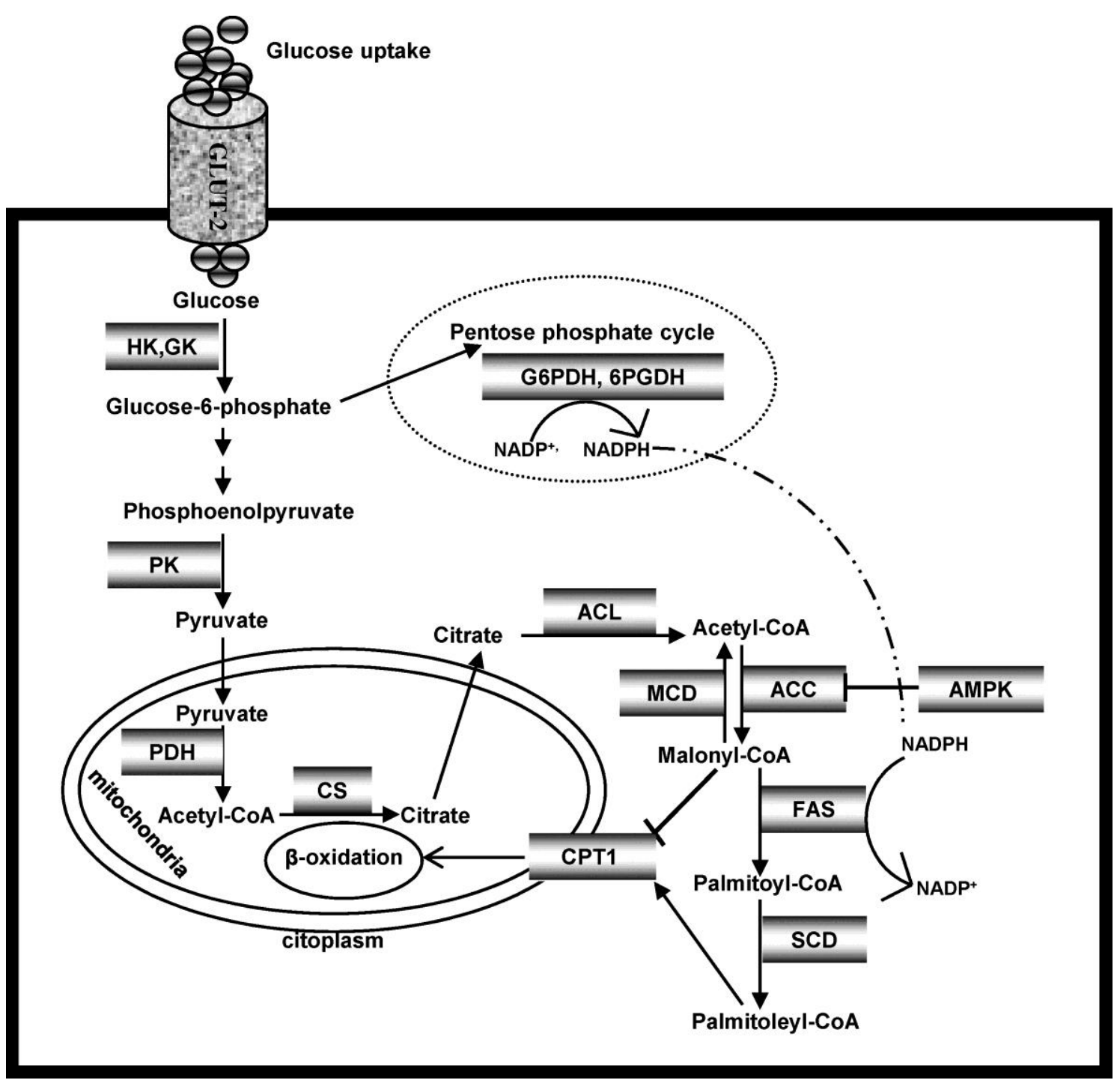

Fig. 9. Glycolytic and lipogenic pathways in the liver.

Here, we demonstrated that ghrelin blockade during the fasting-refeeding cycle with a previously described AG-specific Spiegelmer compound (Shearman et al., 2006), impairs BW recuperation during refeeding. This result suggests a role for AG in the regulation of energy storage following a period of fasting. This finding is in agreement with previous studies in which on the one hand ghrelin neutralization was shown to lead to reduced energy efficiency and to ameliorate obesity in diet-induced obese mice (Shearman et al., 2006) and on the other hand it was demonstrated that treatment with ghrelin induces improved efficiency of food processing (Sangiao-Alvarellos et al., 2009 and Theander-Carrillo et al., 2006). Ghrelin-mediated conservation of energy was shown to be mediated by down-regulation of thermogenesis, energy expenditure and spontaneous locomotor activity and these processes could help to explain the absence of body weight gain during refeeding when ghrelin was neutralized (Jaszberenyi et al., 2006, Tang-Christensen et al., 2004 and Theander-Carrillo et al., 2006). 
Another line of evidence in support of ghrelin's regulatory role in response to nutrient availability was provided in a study by Mayorov et al. in which mice treated with antibodies that hydrolyze the octanoyl moiety of ghrelin to form des-acyl-ghrelin showed greater whole body energy expenditure during fasting than untreated animals (Mayorov et al., 2008), suggesting that AG restrains energy expenditure during fasting.

Our results indicate that the down-regulation of HK and PK activities, observed as a response to fasting, is mitigated by ghrelin neutralization. In addition, the protein and activity levels of enzymes related to lipid synthesis such as FAS, ACC and ATP citrate-lyase also exhibited higher levels during fasting in rats treated with NOX-B11(2) compared to control animals. Similarly, the reduction of 6PDGH and G6PDH activity, two important enzymes for the supply of NADPH for de novo lipogenesis, was also less pronounced by neutralization of AG during $24 \mathrm{~h}$ fasting (Kersten, 2001 and Salati and AmirAhmady, 2001). Overall, these results suggest that blockade of ghrelin during prolonged fasting interferes with the normal down-regulation of the hepatic glycolytic pathway and ultimately of lipogenesis. Our findings illustrate ghrelin's importance during fasting as a key factor to promote the use of fat over glucose in all tissues where possible, and to provide glucose in sufficient amounts for glucose-dependent tissues such as the brain and erythrocytes.

Many studies link the response to food deprivation/restriction to AMPK $\alpha$ as it is an energy sensing kinase which, once activated, promotes energy production and limits energy utilization to ensure cellular survival (Lage et al., 2008). These studies point to the possibility that AMPK $\alpha$ coordinates the changes in enzymes of lipid metabolism during the starved-refed transition (Assifi et al., 2005). It has been demonstrated that administration of ghrelin to rats affects AMPK $\alpha$ activity, although this effect is tissuespecific. In the hypothalamus, central and peripheral ghrelin treatments enhance protein levels of AMPK $\alpha$ and this activation and alterations on lipid metabolism mediate the orexigenic effects of ghrelin (Andersson et al., 2004, Kohno et al., 2008, Kola et al., 2005, Kola et al., 2008 and Lopez et al., 2008). In fed animals peripheral chronic and acute ghrelin treatments provoked AMPK $\alpha$ activation in the heart, while in liver and adipose tissue it was inhibited and no effect was detected on skeletal muscle (Barazzoni et al., 2005 and Kola et al., 2005). In this work we showed that ghrelin neutralization caused lower AMPK $\alpha$ total protein levels after $48 \mathrm{~h}$ of refeeding compared with their controls, just like during $48 \mathrm{~h}$ of fasting. These results suggest that ghrelin's effects are dependent on the energetic status and that its neutralization during fasting and caloric restriction after fasting alters liver metabolism. The data demonstrate the importance of ghrelin in correct nutrient partitioning during negative energy balance. We show that the hepatic levels of pAMPK $\alpha$ and AMPK $\alpha$ are decreased after food deprivation in control SPM and NOX-B11(2) treated rats. However, it should be noted that the ratio of pAMPK to AMPK increased during fasting and decreased after refeeding in both groups (data not shown).

During starvation, the central mechanism to provide the organism with glucose is de novo synthesis in the liver from precursors such as lactate, gluconeogenic amino acids, and glycerol. Likewise, when glucose is directly available from external sources, gluconeogenesis is dispensable and consequently needs to be shut off (Pilkis and Granner, 1992). Insulin is an anabolic hormone that in liver suppresses gluconeogenesis and activates lipogenesis during times of nutritional abundance through the activation of the insulin receptor (IR). Our data indicate that the drop in plasma insulin elicited by fasting is only partially restored following $24 \mathrm{~h}$ and $48 \mathrm{~h}$ of refeeding. Neutralization of ghrelin appears to have a significant inhibitory effect on the recovery of insulin levels during $48 \mathrm{~h}$ of refeeding. Moreover, FBPase levels increase during fasting but are suppressed during refeeding and the finding that FBPase levels are suppressed less in NOX-B11(2) treated animals is consistent with the effect of ghrelin neutralization on insulin levels during refeeding.

When ghrelin was blocked, pAKT, a key protein kinase down-stream of IR (Brunet et al., 1999), exhibited a weaker down-regulation in response to fasting. The results could suggest that ghrelin neutralization during fasting enhances insulin sensitivity in liver, causing a lesser decrease in glucose uptake and consequently in glycolytic and glucogenic pathways. Previously, several works reported differences on insulin sensitivity in animals with deletions in the ghrelin and/or ghrelin receptor genes. Double knockout mice showed a trend towards improved glucose tolerance and insulin sensitivity after an overnight fast (Pfluger et al., 2008). Although these differences were not statistically significant, the findings are supported by independent studies that demonstrate that GHSR and ghrelin null mice display enhanced insulin sensitivity when subjected to caloric restriction or fasting (Sun et al., 2008). Recently Zhao et al. generated GOAT KO mice and they found that when these animals were subject to severe prolonged restriction caloric showed hypoglycemia compared with wild-type, contrary to results observed in this work. However, their caloric restriction was more severe $(60 \%)$ and they only observed differences after 3 days of caloric restriction and when the blood was collected one-half hour before feeding. The authors suggested that GOAT activity and hence acyl-ghrelin levels, that enhanced in wild-type mice during calorie restriction, are necessaries for survival and maintenance of glucose levels of calorie 
restricted mice (Zhao et al., 2010). They observed that GH levels were significantly raised by prolonged caloric restriction however this increased is impaired in GOAT KO mice (Zhao et al., 2010). Their data reveal one essential relation between ghrelin and plasma GH levels during periods of severe calorie restriction, thereby assuring sufficient blood glucose to permit survival. In rats, food deprivation inhibits GH secretion (Muller et al., 1999) and in this study we observed that this decrease was lesser when acylghrelin was neutralized. Different works suggested that food deprivation in rats primarily reduces the activation of insulin signaling for glucose metabolism through reduction of GH and/or subsequent IGF-1 signaling (Hayashi et al., 2008). The data obtained in our study and GOAT KO mice (Zhao et al., 2010) would reveal one function of ghrelin in maintenance of appropriate plasma GH levels during periods of fasting or food restriction. Recently Chiba et al. suggested a model where NPY and ghrelin play a crucial role during food deprivation in rats (Chiba et al., 2009). They proposed that caloric restriction decreased plasma insulin and leptin levels, whereas it increased ghrelin levels and that these hormonal changes result in an increased NPY expression in the arcuate nucleus. NPY/AgRP neurons project their axons to down-stream neurons such as GHRH neurons suppressing them. They also suggested that NPY upregulation could also enhance oxidative stress resistance and hepatic glucose production (Chiba et al., 2009). In addition, intraventricular injection of NPY inhibited GH secretion, and a NPY antiserum led to elevated plasma GH levels and partially restored GH secretory pulses in food-deprived rats (Muller et al., 1999). Acyl-ghrelin neutralization during food deprivation might do that the increase of the NPY was minor, which might explain a minor decrease in plasma GH levels and some of the changes observed in the hepatic metabolism, nevertheless further studies are necessary to demonstrate this theory.

We did not observed changes in glucose levels during fasting in animals treated with NOX-B11(2) compared with their controls, although our results showed that neutralization of ghrelin during fasting contributes to incorrect inhibition of hepatic glycolysis and lipogenesis. Other studies with more prolonged fasting and caloric restrictions could to help to clarify these results.

Insulin promotes the storage and synthesis of lipids, protein, and carbohydrates (Saltiel and Kahn, 2001). The first step by which insulin increases energy storage or utilization involves the regulated transport of glucose into the cell (Chang et al., 2004) hence, lower insulin levels observed during refeeding in NOX-B11(2) treated rats could help explain lower level of hepatic glycogen and slightly higher glycemia that showed these animals. On the other hand, the insulin receptor substrate (IRS) proteins, initiates activation of the phosphatidylinositol 3-kinase pathway, resulting in stimulation of protein kinases such as AKT (Chang et al., 2004) that suppresses gluconeogenesis and activates glycogen synthesis via phosphorylation of FOXO1 (Zhang et al., 2002) and GSK-3 (Cross et al., 1995) respectively. Phosphorylation of GSK-3 inactivates GSK-3 kinase activity and leads to increased activity of glycogen synthetase (GS), resulting in enhanced glycogen deposition (Cross et al., 1995). For these reasons, the decrease in insulin levels and AKT phosphorylation after $48 \mathrm{~h}$ refeeding when ghrelin was blocked, could elucidate the decrease in glycogen levels present in the animals. However, further studies are necessary to clarify this hypothesis.

In summary, our study delineates several lines of evidence that implicate ghrelin as an important regulator of the response to changes in energy availability: First, ghrelin neutralization during the fastingrefeeding cycle interferes with normal recovery of body weight; second, the fasting-induced rise in ghrelin levels contributes to inhibition of hepatic glycolysis and lipogenesis, which appears to be linked to insulin sensitivity; and third, once food becomes available following the fasting, ghrelin promotes lipogenesis recovery and favors glycogen deposition in order to minimize negative effects from periods of food scarcity.

The results point to ghrelin as a key player in regulating the enzymatic activities involved in restoring body weight following diet-induced weight loss. Ghrelin may thus be a relevant target in controlling the well-known phenomenon of patients quickly regaining weight that was lost in the course of a diet. Moreover, ghrelin manipulation could be therapeutically relevant to avoid refeeding syndrome, a potentially fatal clinical syndrome related to the treatment of malnutrition, which is associated with very low ghrelin levels (Korbonits et al., 2007). The understanding of ghrelin's role in the molecular mechanisms underlying the events that occur during fasting and refeeding will hopefully lead to new strategies for the design and development of suitable drugs for the treatment of pathologies of obesity, its co-morbidities, and other endocrine disorders affecting energy metabolism.

\section{Acknowledgements}

We thank Dr. Klaus Buchner for invaluable help with the studies about the capacity of the Spiegelmer for neutralize acyl-ghrelin. This work has been supported in part by: FIS del Instituto de Salud Carlos IIIPI070413 and Xunta de GaliciaPS07/12, PGIDT05PXIC91605PN, INCITE08ENA916110ES and Redes 2006/27, Spain. 


\section{References}

Ames, 2006. B.N. Ames. Low micronutrient intake may accelerate the degenerative diseases of aging through allocation of scarce micronutrients by triage. Proc. Natl. Acad. Sci. U.S.A., 103 (2006), pp. 17589-17594.

Andersson et al., 2004. U. Andersson, K. Filipsson, C.R. Abbott, A. Woods, K. Smith, S.R. Bloom, D. Carling, C.J. Small. AMP-activated protein kinase plays a role in the control of food intake. J. Biol. Chem., 279 (2004), pp. 12005-12008.

Ariyasu et al., 2005. H. Ariyasu, K. Takaya, H. Iwakura, H. Hosoda, T. Akamizu, Y. Arai, K. Kangawa, K. Nakao. Transgenic mice overexpressing des-acyl ghrelin show small phenotype. Endocrinology, 146 (2005), pp. 355364.

Asakawa et al., 2005. A. Asakawa, A. Inui, M. Fujimiya, R. Sakamaki, N. Shinfuku, Y. Ueta, M.M. Meguid, M. Kasuga. Stomach regulates energy balance via acylated ghrelin and desacyl ghrelin. Gut, 54 (2005), pp. 18-24.

Assifi et al., 2005. M.M. Assifi, G. Suchankova, S. Constant, M. Prentki, A.K. Saha, N.B. Ruderman. AMP-activated protein kinase and coordination of hepatic fatty acid metabolism of starved/carbohydrate-refed rats. Am. J. Physiol. Endocrinol. Metab., 289 (2005), pp. E794-E800.

Baldanzi et al., 2002. G. Baldanzi, N. Filigheddu, S. Cutrupi, F. Catapano, S. Bonissoni, A. Fubini, D. Malan, G. Baj, R. Granata, F. Broglio, M. Papotti, N. Surico, F. Bussolino, J. Isgaard, R. Deghenghi, F. Sinigaglia, M. Prat, G. Muccioli, E. Ghigo, A. Graziani. Ghrelin and des-acyl ghrelin inhibit cell death in cardiomyocytes and endothelial cells through ERK1/2 and PI 3-kinase/AKT. J. Cell Biol., 159 (2002), pp. 1029-1037.

Barazzoni et al., 2005. R. Barazzoni, A. Bosutti, M. Stebel, M.R. Cattin, E. Roder, L. Visintin, L. Cattin, G. Biolo, M. Zanetti, G. Guarnieri. Ghrelin regulates mitochondrial-lipid metabolism gene expression and tissue fat distribution in liver and skeletal muscle. Am. J. Physiol. Endocrinol. Metab., 288 (2005), pp. E228-E235.

Barazzoni et al., 2007. R. Barazzoni, M. Zanetti, M.R. Cattin, L. Visintin, P. Vinci, L. Cattin, M. Stebel, G. Guarnieri. Ghrelin enhances in vivo skeletal muscle but not liver AKT signaling in rats. Obesity (Silver Spring), 15 (2007), pp. 2614-2623.

Broglio et al., 2001. F. Broglio, E. Arvat, A. Benso, C. Gottero, G. Muccioli, M. Papotti, van der LelyF A.J., R. Deghenghi, E. Ghigo. a natural GH secretagogue produced by the stomach, induces hyperglycemia and reduces insulin secretion in humans. J. Clin. Endocrinol. Metab., 86 (2001), pp. 5083-5086.

Broglio et al., 2003. F. Broglio, C. Gottero, A. Benso, F. Prodam, S. Destefanis, C. Gauna, M. Maccario, R. Deghenghi, A.J. van der Lely, E. Ghigo. Effects of ghrelin on the insulin and glycemic responses to glucose, arginine, or free fatty acids load in humans. J. Clin. Endocrinol. Metab., 88 (2003), pp. 4268-4272.

Brunet et al., 1999. A. Brunet, A. Bonni, M.J. Zigmond, M.Z. Lin, P. Juo, L.S. Hu, M.J. Anderson, K.C. Arden, J. Blenis, M.E. Greenberg. Akt promotes cell survival by phosphorylating and inhibiting a Forkhead transcription factor. Cell, 96 (1999), pp. 857-868.

Chang et al., 2004. L. Chang, S.H. Chiang, A.R. Saltiel. Insulin signaling and the regulation of glucose transport. Mol. Med., 10 (2004), pp. 65-71.

Chiba et al., 2009. T. Chiba, T. Komatsu, M. Nakayama, T. Adachi, Y. Tamashiro, H. Hayashi, H. Yamaza, Y. Higami, I. Shimokawa. Similar metabolic responses to calorie restriction in lean and obese Zucker rats. Mol. Cell. Endocrinol., 309 (2009), pp. 17-25.

Chung et al., 2008. H. Chung, S. Seo, M. Moon, S. Park. Phosphatidylinositol-3-kinase/Akt/glycogen synthase kinase-3 beta and ERK1/2 pathways mediate protective effects of acylated and unacylated ghrelin against oxygen-glucose deprivation-induced apoptosis in primary rat cortical neuronal cells. J. Endocrinol., 198 (2008), pp. 511-521.

Corrigan and Rider, 1983. A.P. Corrigan, C.C. Rider. Multiple chromatographic forms of ATP citrate lyase from rat liver. Biochem. J., 214 (1983), pp. 299-307.

Cross et al., 1995. D.A. Cross, D.R. Alessi, P. Cohen, M. Andjelkovich, B.A. Hemmings. Inhibition of glycogen synthase kinase-3 by insulin mediated by protein kinase B. Nature, 378 (1995), pp. 785-789.

Cui et al., 2008. C. Cui, H. Ohnuma, M. Daimon, S. Susa, H. Yamaguchi, W. Kameda, Y. Jimbu, T. Oizumi, T. Kato. Ghrelin infused into the portal vein inhibits glucose-stimulated insulin secretion in Wistar rats. Peptides, 29 (2008), pp. 1241-1246

Cummings et al., 2001. D.E. Cummings, J.Q. Purnell, R.S. Frayo, K. Schmidova, B.E. Wisse, D.S. Weigle. A preprandial rise in plasma ghrelin levels suggests a role in meal initiation in humans. Diabetes, 50 (2001), pp. $1714-1719$.

Cummings et al., 2002. D.E. Cummings, D.S. Weigle, R.S. Frayo, P.A. Breen, M.K. Ma, E.P. Dellinger, J.Q. Purnell. Plasma ghrelin levels after diet-induced weight loss or gastric bypass surgery. N. Engl. J. Med., 346 (2002), pp. 1623-1630.

Davidson and Arion, 1987. A.L. Davidson, W.J. Arion. Factors underlying significant underestimations of glucokinase activity in crude liver extracts: physiological implications of higher cellular activity. Arch. Biochem. Biophys., 253 (1987), pp. 156-167.

Denton et al., 1979. R.M. Denton, N.J. Edgell, B.J. Bridges, G.P. Poole. Acute regulation of pyruvate kinase activity in rat epididymal adipose tissue by insulin. Biochem. J., 180 (1979), pp. 523-531.

Foufelle and Ferre, 2002. F. Foufelle, P. Ferre. New perspectives in the regulation of hepatic glycolytic and lipogenic genes by insulin and glucose: a role for the transcription factor sterol regulatory element binding protein-1c. Biochem. J., 366 (2002), pp. 377-391.

Gauna et al., 2004. C. Gauna, F.M. Meyler, J.A. Janssen, P.J. Delhanty, T. Abribat, P. van Koetsveld, L.J. Hofland, F. Broglio, E. Ghigo, A.J. van der Lely. Administration of acylated ghrelin reduces insulin sensitivity, whereas the 
combination of acylated plus unacylated ghrelin strongly improves insulin sensitivity. J. Clin. Endocrinol. Metab., 89 (2004), pp. 5035-5042. .

Gutierrez et al., 2008. J.A. Gutierrez, P.J. Solenberg, D.R. Perkins, J.A. Willency, M.D. Knierman, Z. Jin, D.R. Witcher, S. Luo, J.E. Onyia, J.E. Hale. Ghrelin octanoylation mediated by an orphan lipid transferase. Proc. Natl. Acad. Sci. U.S.A., 105 (2008), pp. 6320-6325.

Hayashi et al., 2008. H. Hayashi, H. Yamaza, T. Komatsu, S. Park, T. Chiba, Y. Higami, T. Nagayasu, I. Shimokawa. Calorie restriction minimizes activation of insulin signaling in response to glucose: potential involvement of the growth hormone-insulin-like growth factor 1 axis. Exp. Gerontol., 43 (2008), pp. 827-832.

Helmling et al., 2004. S. Helmling, C. Maasch, D. Eulberg, K. Buchner, W. Schroder, C. Lange, S. Vonhoff, B. Wlotzka, M.H. Tschop, S. Rosewicz, S. Klussmann. Inhibition of ghrelin action in vitro and in vivo by an RNASpiegelmer. Proc. Natl. Acad. Sci. U.S.A., 101 (2004), pp. 13174-13179.

Hofbauer et al., 2007. K.G. Hofbauer, J.R. Nicholson, O. Boss. The obesity epidemic: current and future pharmacological treatments. Annu. Rev. Pharmacol. Toxicol., 47 (2007), pp. 565-592.

Howard et al., 1996. A.D. Howard, S.D. Feighner, D.F. Cully, J.P. Arena, P.A. Liberator, C.I. Rosenblum, M. Hamelin, D.L. Hreniuk, O.C. Palyha, J. Anderson, P.S. Paress, C. Diaz, M. Chou, K.K. Liu, K.K. McKee, S.S. Pong, L.Y. Chaung, A. Elbrecht, M. Dashkevicz, R. Heavens, M. Rigby, D.J. Sirinathsinghji, D.C. Dean, D.G. Melillo, A.A. Patchett, R. Nargund, P.R. Griffin, J.A. DeMartino, S.K. Gupta, J.M. Schaeffer, R.G. Smith, L.H. Van der Ploeg. A receptor in pituitary and hypothalamus that functions in growth hormone release. Science, 273 (1996), pp. 974-977.

Ikezaki et al., 2002. A. Ikezaki, H. Hosoda, K. Ito, S. Iwama, N. Miura, H. Matsuoka, C. Kondo, M. Kojima, K. Kangawa, S. Sugihara. Fasting plasma ghrelin levels are negatively correlated with insulin resistance and PAI-1, but not with leptin, in obese children and adolescents. Diabetes, 51 (2002), pp. 3408-3411.

Iwakura et al., 2005. H. Iwakura, K. Hosoda, C. Son, J. Fujikura, T. Tomita, M. Noguchi, H. Ariyasu, K. Takaya, H. Masuzaki, Y. Ogawa, T. Hayashi, G. Inoue, T. Akamizu, H. Hosoda, M. Kojima, H. Itoh, S. Toyokuni, K. Kangawa, K. Nakao. Analysis of rat insulin II promoter-ghrelin transgenic mice and rat glucagon promoterghrelin transgenic mice. J. Biol. Chem., 280 (2005), pp. 15247-15256.

Jaszberenyi et al., 2006. M. Jaszberenyi, E. Bujdoso, Z. Bagosi, G. Telegdy. Mediation of the behavioral, endocrine and thermoregulatory actions of ghrelin. Horm. Behav., 50 (2006), pp. 266-273.

Karlic et al., 2002. H. Karlic, S. Lohninger, T. Koeck, A. Lohninger. Dietary l-carnitine stimulates carnitine acyltransferases in the liver of aged rats. J. Histochem. Cytochem., 50 (2002), pp. 205-212.

Keppler and Decker, 1974. D. Keppler, K. Decker. Glycogen determination with amyloglucosidase. H.U. Bergmeyer (Ed.), Methods of Enzymatic Analysis, vol. 3Academic Press, New York (1974), pp. 127-1131.

Kersten, 2001. S. Kersten. Mechanisms of nutritional and hormonal regulation of lipogenesis. EMBO Rep., 2 (2001), pp. 282-286.

Kirchner et al., 2009. H. Kirchner, J.A. Gutierrez, P.J. Solenberg, P.T. Pfluger, T.A. Czyzyk, J.A. Willency, A. Schurmann, H.G. Joost, R.J. Jandacek, J.E. Hale, M.L. Heiman, M.H. Tschop. GOAT links dietary lipids with the endocrine control of energy balance. Nat. Med., 15 (2009), pp. 741-745.

Kobelt et al., 2006. P. Kobelt, S. Helmling, A. Stengel, B. Wlotzka, V. Andresen, B.F. Klapp, B. Wiedenmann, S. Klussmann, H. Monnikes. Anti-ghrelin Spiegelmer NOX-B11 inhibits neurostimulatory and orexigenic effects of peripheral ghrelin in rats. Gut, 55 (2006), pp. 788-792.

Kohno et al., 2008. D. Kohno, H. Sone, Y. Minokoshi, T. Yada. Ghrelin raises $\left[\mathrm{Ca}^{2+}\right]$ i via AMPK in hypothalamic arcuate nucleus NPY neurons. Biochem. Biophys. Res. Commun., 366 (2008), pp. 388-392.

Kojima et al., 1999. M. Kojima, H. Hosoda, Y. Date, M. Nakazato, H. Matsuo, K. Kangawa. Ghrelin is a growthhormone-releasing acylated peptide from stomach. Nature, 402 (1999), pp. 656-660.

Kojima et al., 2001a. M. Kojima, H. Hosoda, K. Kangawa. Purification and distribution of ghrelin: the natural endogenous ligand for the growth hormone secretagogue receptor. Horm. Res., 56 (Suppl. 1) (2001), pp. 93-97.

Kojima et al., 2001b. M. Kojima, H. Hosoda, H. Matsuo, K. Kangawa. Ghrelin: discovery of the natural endogenous ligand for the growth hormone secretagogue receptor. Trends Endocrinol. Metab., 12 (2001), pp. 118-122.

Kola et al., 2008. B. Kola, I. Farkas, M. Christ-Crain, G. Wittmann, F. Lolli, F. Amin, J. Harvey-White, Z. Liposits, G. Kunos, A.B. Grossman, C. Fekete, M. Korbonits. The orexigenic effect of ghrelin is mediated through central activation of the endogenous cannabinoid system. PLoS ONE, 3 (2008), p. e1797.

Kola et al., 2005. B. Kola, E. Hubina, S.A. Tucci, T.C. Kirkham, E.A. Garcia, S.E. Mitchell, L.M. Williams, S.A. Hawley, D.G. Hardie, A.B. Grossman, M. Korbonits. Cannabinoids and ghrelin have both central and peripheral metabolic and cardiac effects via AMP-activated protein kinase. J. Biol. Chem., 280 (2005), pp. 25196-25201.

Korbonits et al., 2007. M. Korbonits, D. Blaine, M. Elia, J. Powell-Tuck. Metabolic and hormonal changes during the refeeding period of prolonged fasting. Eur. J. Endocrinol., 157 (2007), pp. 157-166.

Lage et al., 2008. R. Lage, C. Dieguez, A. Vidal-Puig, M. Lopez. AMPK: a metabolic gauge regulating whole-body energy homeostasis. Trends Mol. Med., 14 (2008), pp. 539-549.

Liu et al., 2008. J. Liu, C.E. Prudom, R. Nass, S.S. Pezzoli, M.C. Oliveri, M.L. Johnson, P. Veldhuis, D.A. Gordon, A.D. Howard, D.R. Witcher, H.M. Geysen, B.D. Gaylinn, M.O. Thorner. Novel ghrelin assays provide evidence for independent regulation of ghrelin acylation and secretion in healthy young men. J. Clin. Endocrinol. Metab., 93 (2008), pp. 1980-1987.

Longo et al., 2008. K.A. Longo, S. Charoenthongtrakul, D.J. Giuliana, E.K. Govek, T. McDonagh, Y. Qi, P.S. Distefano, B.J. Geddes. Improved insulin sensitivity and metabolic flexibility in ghrelin receptor knockout mice. Regul. Pept., 150 (2008), pp. 55-61. 
Lopez et al., 2008. M. Lopez, R. Lage, A.K. Saha, D. Perez-Tilve, M.J. Vazquez, L. Varela, S. Sangiao-Alvarellos, S. Tovar, K. Raghay, S. Rodriguez-Cuenca, R.M. Deoliveira, T. Castaneda, R. Datta, J.Z. Dong, M. Culler, M.W. Sleeman, C.V. Alvarez, R. Gallego, C.J. Lelliott, D. Carling, M.H. Tschop, C. Dieguez, A. Vidal-Puig. Hypothalamic fatty acid metabolism mediates the orexigenic action of ghrelin. Cell Metab., 7 (2008), pp. 389399.

Mayorov et al., 2008. A.V. Mayorov, N. Amara, J.Y. Chang, J.A. Moss, M.S. Hixon, D.I. Ruiz, M.M. Meijler, E.P. Zorrilla, K.D. Janda. Catalytic antibody degradation of ghrelin increases whole-body metabolic rate and reduces refeeding in fasting mice. Proc. Natl. Acad. Sci. U.S.A., 105 (2008), pp. 17487-17492.

Muller et al., 1999. E.E. Muller, V. Locatelli, D. Cocchi. Neuroendocrine control of growth hormone secretion. Physiol. Rev., 79 (1999), pp. 511-607.

Nakazato et al., 2001. M. Nakazato, N. Murakami, Y. Date, M. Kojima, H. Matsuo, K. Kangawa, S. Matsukura. A role for ghrelin in the central regulation of feeding. Nature, 409 (2001), pp. 194-198.

Pacifico et al., 2009. L. Pacifico, E. Poggiogalle, F. Costantino, C. Anania, F. Ferraro, F. Chiarelli, C. Chiesa. Acylated and nonacylated ghrelin levels and their associations with insulin resistance in obese and normal weight children with metabolic syndrome. Eur. J. Endocrinol., 161 (2009), pp. 861-870.

Pfluger et al., 2008. P.T. Pfluger, H. Kirchner, S. Gunnel, B. Schrott, D. Perez-Tilve, S. Fu, S.C. Benoit, T. Horvath, H.G. Joost, K.E. Wortley, M.W. Sleeman, M.H. Tschop. Simultaneous deletion of ghrelin and its receptor increases motor activity and energy expenditure. Am. J. Physiol. Gastrointest. Liver Physiol., 294 (2008), pp. G610-G618.

Pilkis and Granner, 1992. S.J. Pilkis, D.K. Granner. Molecular physiology of the regulation of hepatic gluconeogenesis and glycolysis. Annu. Rev. Physiol., 54 (1992), pp. 885-909.

Rossi et al., 2008. F. Rossi, A. Castelli, M.J. Bianco, C. Bertone, M. Brama, V. Santiemma. Ghrelin induces proliferation in human aortic endothelial cells via ERK1/2 and PI3K/Akt activation. Peptides, 29 (2008), pp. 2046-2051.

Saggerson and Greenbaum, 1970. E.D. Saggerson, A.L. Greenbaum. The regulation of triglyceride synthesis and fatty acid synthesis in rat epididymal adipose tissue. Effects of altered dietary and hormonal conditions. Biochem. J., 119 (1970), pp. 221-242.

Salati and Amir-Ahmady, 2001. L.M. Salati, B. Amir-Ahmady. Dietary regulation of expression of glucose-6phosphate dehydrogenase. Annu. Rev. Nutr., 21 (2001), pp. 121-140.

Saltiel and Kahn, 2001. A.R. Saltiel, C.R. Kahn. Insulin signalling and the regulation of glucose and lipid metabolism. Nature, 414 (2001), pp. 799-806.

Sangiao-Alvarellos et al., 2009. S. Sangiao-Alvarellos, M.J. Vazquez, L. Varela, R. Nogueiras, A.K. Saha, F. Cordido, M. Lopez, C. Dieguez. Central ghrelin regulates peripheral lipid metabolism in a growth hormoneindependent fashion. Endocrinology, 150 (2009), pp. 4562-4574.

Seoane et al., 2004. L.M. Seoane, S.A. Tovar, D. Perez, F. Mallo, M. Lopez, R. Senaris, F.F. Casanueva, C. Dieguez. Orexin A suppresses in vivo GH secretion. Eur. J. Endocrinol., 150 (2004), pp. 731-736.

Shearman et al., 2006. L.P. Shearman, S.P. Wang, S. Helmling, D.S. Stribling, P. Mazur, L. Ge, L. Wang, S. Klussmann, D.E. Macintyre, A.D. Howard, A.M. Strack. Ghrelin neutralization by a ribonucleic acid-SPM ameliorates obesity in diet-induced obese mice. Endocrinology, 147 (2006), pp. 1517-1526.

Shiiya et al., 2002. T. Shiiya, M. Nakazato, M. Mizuta, Y. Date, M.S. Mondal, M. Tanaka, S. Nozoe, H. Hosoda, K. Kangawa, S. Matsukura. Plasma ghrelin levels in lean and obese humans and the effect of glucose on ghrelin secretion. J. Clin. Endocrinol. Metab., 87 (2002), pp. 240-244.

Shin et al., 2006. E.S. Shin, S.Y. Cho, E.H. Lee, S.J. Lee, I.S. Chang, T.R. Lee. Positive regulation of hepatic carnitine palmitoyl transferase 1A (CPT1A) activities by soy isoflavones and l-carnitine. Eur. J. Nutr., 45 (2006), pp. 159-164.

St-Pierre et al., 2007. D.H. St-Pierre, A.D. Karelis, L. Coderre, F. Malita, J. Fontaine, D. Mignault, M. Brochu, J.P. Bastard, K. Cianflone, E. Doucet, P. Imbeault, R. Rabasa-Lhoret. Association of acylated and nonacylated ghrelin with insulin sensitivity in overweight and obese postmenopausal women. J. Clin. Endocrinol. Metab., 92 (2007), pp. 264-269.

Sun et al., 2003. Y. Sun, S. Ahmed, R.G. Smith. Deletion of ghrelin impairs neither growth nor appetite. Mol. Cell. Biol., 23 (2003), pp. 7973-7981.

Sun et al., 2006. Y. Sun, M. Asnicar, P.K. Saha, L. Chan, R.G. Smith. Ablation of ghrelin improves the diabetic but not obese phenotype of ob/ob mice. Cell Metab., 3 (2006), pp. 379-386.

Sun et al., 2008. Y. Sun, N.F. Butte, J.M. Garcia, R.G. Smith. Characterization of adult ghrelin and ghrelin receptor knockout mice under positive and negative energy balance. Endocrinology, 149 (2008), pp. 843-850.

Tang-Christensen et al., 2004. M. Tang-Christensen, N. Vrang, S. Ortmann, M. Bidlingmaier, T.L. Horvath, M. Tschop. Central administration of ghrelin and agouti-related protein (83-132) increases food intake and decreases spontaneous locomotor activity in rats. Endocrinology, 145 (2004), pp. 4645-4652.

Theander-Carrillo et al., 2006. C. Theander-Carrillo, P. Wiedmer, P. Cettour-Rose, R. Nogueiras, D. Perez-Tilve, P. Pfluger, T.R. Castaneda, P. Muzzin, A. Schurmann, I. Szanto, M.H. Tschop, F. Rohner-Jeanrenaud. Ghrelin action in the brain controls adipocyte metabolism. J. Clin. Invest., 116 (2006), pp. 1983-1993.

Tian et al., 1999. W.N. Tian, L.D. Braunstein, K. Apse, J. Pang, M. Rose, X. Tian, R.C. Stanton. Importance of glucose-6-phosphate dehydrogenase activity in cell death. Am. J. Physiol., 276 (1999), pp. C1121-C1131.

Tian et al., 1998. W.N. Tian, L.D. Braunstein, J. Pang, K.M. Stuhlmeier, Q.C. Xi, X. Tian, R.C. Stanton. Importance of glucose-6-phosphate dehydrogenase activity for cell growth. J. Biol. Chem., 273 (1998), pp. 10609-10617.

Tschop et al., 2000. M. Tschop, D.L. Smiley, M.L. Heiman. Ghrelin induces adiposity in rodents. Nature, 407 (2000), pp. 908-913. 
Tschop et al., 2001a. M. Tschop, R. Wawarta, R.L. Riepl, S. Friedrich, M. Bidlingmaier, R. Landgraf, C. Folwaczny. Post-prandial decrease of circulating human ghrelin levels. J. Endocrinol. Invest., 24 (2001), pp. RC19-RC21.

Tschop et al., 2001b. M. Tschop, C. Weyer, P.A. Tataranni, V. Devanarayan, E. Ravussin, M.L. Heiman. Circulating ghrelin levels are decreased in human obesity. Diabetes, 50 (2001), pp. 707-709.

Van der Lely et al., 2004. A.J. Van der Lely, M. Tschop, M.L. Heiman, E. Ghigo. Biological, physiological, pathophysiological, and pharmacological aspects of ghrelin. Endocr. Rev., 25 (2004), pp. 426-457.

Vestergaard et al., 2008a. E.T. Vestergaard, C.B. Djurhuus, J. Gjedsted, S. Nielsen, N. Moller, J.J. Holst, J.O. Jorgensen, O. Schmitz. Acute effects of ghrelin administration on glucose and lipid metabolism. J. Clin. Endocrinol. Metab., 93 (2008), pp. 438-444.

Vestergaard et al., 2008b. E.T. Vestergaard, L.C. Gormsen, N. Jessen, S. Lund, T.K. Hansen, N. Moller, J.O. Jorgensen. Ghrelin infusion in humans induces acute insulin resistance and lipolysis independent of growth hormone signaling. Diabetes, 57 (2008), pp. 3205-3210.

Westbury and Hahn, 1984. K. Westbury, P. Hahn. Fructose-1,6-biphosphatase activity in the intestinal mucosa of developing rats. Am. J. Physiol., 246 (1984), pp. G683-G686.

Wren et al., 2001a. A.M. Wren, L.J. Seal, M.A. Cohen, A.E. Brynes, G.S. Frost, K.G. Murphy, W.S. Dhillo, M.A. Ghatei, S.R. Bloom. Ghrelin enhances appetite and increases food intake in humans. J. Clin. Endocrinol. Metab., 86 (2001), p. 5992.

Wren et al., 2001b. A.M. Wren, C.J. Small, C.R. Abbott, W.S. Dhillo, L.J. Seal, M.A. Cohen, R.L. Batterham, S. Taheri, S.A. Stanley, M.A. Ghatei, S.R. Bloom. Ghrelin causes hyperphagia and obesity in rats. Diabetes, 50 (2001), pp. 2540-2547.

Yada et al., 2008. T. Yada, K. Dezaki, H. Sone, M. Koizumi, B. Damdindorj, M. Nakata, M. Kakei. Ghrelin regulates insulin release and glycemia: physiological role and therapeutic potential. Curr. Diabetes Rev., 4 (2008), pp. 1823.

Yang et al., 2007. H. Yang, Y.H. Youm, C. Nakata, V.D. Dixit. Chronic caloric restriction induces forestomach hypertrophy with enhanced ghrelin levels during aging. Peptides, 28 (2007), pp. 1931-1936.

Yang et al., 2008. J. Yang, M.S. Brown, G. Liang, N.V. Grishin, J.L. Goldstein. Identification of the acyltransferase that octanoylates ghrelin, an appetite-stimulating peptide hormone. Cell, 132 (2008), pp. 387-396.

Zhang et al., 2002. X. Zhang, L. Gan, H. Pan, S. Guo, X. He, S.T. Olson, A. Mesecar, S. Adam, T.G. Unterman. Phosphorylation of serine 256 suppresses transactivation by FKHR (FOXO1) by multiple mechanisms. Direct and indirect effects on nuclear/cytoplasmic shuttling and DNA binding. J. Biol. Chem., 277 (2002), pp. 4527645284.

Zhao et al., 2010. T.J. Zhao, G. Liang, R.L. Li, X. Xie, M.W. Sleeman, A.J. Murphy, D.M. Valenzuela, G.D. Yancopoulos, J.L. Goldstein, M.S. Brown. Ghrelin O-acyltransferase (GOAT) is essential for growth hormonemediated survival of calorie-restricted mice. Proc. Natl. Acad. Sci. U.S.A., 107 (2010), pp. 7467-7472. 